\title{
19- Yabancı dil olarak Türkçeyi uzaktan öğretenlerin uzaktan öğretime ilişkin metaforik algıları
}

Aysun EROĞLU1

Alpaslan OKUR²

APA: Eroğlu, A.; Okur, A. (2021). Yabancı dil olarak Türkçeyi uzaktan öğretenlerin uzaktan öğretime ilişkin metaforik algıları. RumeliDE Dil ve Edebiyat Araştırmaları Dergisi, (Ö10), 325-338. DOI: 10.2900o/rumelide.1011455.

$\ddot{O} \mathbf{z}$

$\mathrm{Bu}$ araştırmanın amacı yabancı dil olarak Türkçeyi uzaktan öğretenlerin uzaktan öğretime ilişkin metaforik algılarını ortaya çıkarmaktır. Bu amaç doğrultusunda nitel araştırma yöntemlerinden olgu bilim (fenomenoloji) kullanılmıştır. Araştırmada 2020-2021 eğitim-öğretim yılının bahar döneminde Türkiye'nin farklı illerinde yabancılara Türkçe öğreten 58 kadın, 25 erkek toplam 83 katılımcı yer almıştır. Veriler yabancılara Türkçe öğreticileri için hazırlanan metafor formundan elde edilmiştir. Verilerin toplanması için oluşturulan metafor formunda, yönerge kısmı, demografik bilgiler kısmı ve metafor kısmı bulunmaktadır. Yönerge kısmında, çalışmanın amacı belirtilip paylaşılan bilgilerin gizli kalacağı, çalışma sonucunu merak edenler için mail adresi bulunmaktadır. Demografik bilgiler kısmında, katılımcılara ait cinsiyet, yaş, görev süresi, ders verilen teknolojik aracın ve internetin temin şekli gibi bilgiler yer almaktadır. Form GoogleDocs aracılı̆̆ıyla oluşturulmuş ve öğreticilerle form link paylaşılmış ve formu doldurmaları istenmiştir. Doldurulan formlar araştırmanın verilerini oluşturmuştur. Katılımcılardan tarafindan doldurulan form excel programına otomatik kaydedilmiştir. Araştırmada içerik analizi kullanılmıştır. Analiz yapılırken excelden word dosyasına veriler kategorilere ayrılıp ortak özellikte olanlar bir araya getirilerek tablolar şeklinde kaydedilmiştir. Araştırmanın geçerlik ve güvenirliği sağlamak için de iki uzmanla değerlendirme toplantısı yapılmıştır. Araştırma sonucunda yabancılara Türkçe öğretenlerin uzaktan öğretime ilişkin kültür, zor, keyifli, yenilik, emek, yemek ve diğer olmak üzere toplam yedi kategori oluşturduğu bulunmuştur. Yabancılara Türkçe öğreticilerin uzaktan öğretimine ilişkin en çok kültür kategorisinde metafor oluşturdukları kaydedilmiştir.

Anahtar kelimeler: Yabancı dil olarak Türkçeyi uzaktan öğretmek, Yabancılara Türkçe öğretenler, metafor, nitel araştırma

\section{Metaphorical Perceptions of Teachers of Turkish as a foreign language online}

\author{
Abstract \\ The purpose of this study is to seek into the metaphorical perceptions of teachers of Turkish as a \\ foreign language. Phenomenology among qualitative methods was employed. The study group was \\ composed of 83 participants ( 58 women and 25 men ) who teach Turkish to foreigners in different \\ cities of Turkey during 2020-2021 the spring term of the academic year. Metaphor form was used as \\ data collection tool. The form includes a directive part, a demographic information part and a \\ Arş. Gör. Dr., Kafkas Üniversitesi, Eğitim Fakültesi, Türkçe Eğitimi ABD (Kars, Türkiye), 24aysun@gmail.com, ORCID \\ ID: 0000-0003-1047-8748 [Araştırma makalesi, Makale kayıt tarihi: 15.10.2021-kabul tarihi: 20.10.2021; DOI: \\ 10.29000/rumelide.1011455] \\ Prof. Dr., Sakarya Üniversitesi, Eğitim Fakültesi, Türkçe ve Sosyal Bilimler ABD, Türkçe Eğitimi BD (Sakarya, Türkiye). \\ aokur@sakarya.edu.tr, ORCID ID : 0000-0002-2868-063X \\ Adres $\mid$ Address \\ RumeliDE Dil ve Edebiyat Araştırmaları Dergisi $\quad$ RumeliDE Journal of Language and Literature Studies \\ Osmanağa Mahallesi, Mürver Çiçeği Sokak, No:14/8 $\quad$ Osmanağa Mahallesi, Mürver Çiçeği Sokak, No:14/8 \\ Kadıköy - ISTANBUL / TÜRKIYE 34714 Kadıköy - ISTANBUL / TURKEY 34714 \\ e-posta: editor@rumelide.com e-mail: editor@rumelide.com, \\ tel: +90 505 7958124, +90 2167730616 phone: +90 505 7958124, +90 2167730616
}


metaphor part. In the instruction part, the purpose of the research and shared information's confidentiality are stated, and there is an e-mail address for those who are curious about the result of the research. In the demographic information section, there is information such as participant's gender, age, place of work, duration of work, the technological tools they use and the way the internet is provided. Research data was collected with GoogleDocs. The link of form was shared with the participants and asked participants to fill in the form. The collected data was saved in the excel program. Content analysis was used in the research. During the analysis, the data from excel to word file were divided into categories and the ones with common specifications were brought together and recorded in the form of tables. For ensuring the validity and reliability of the research, an evaluation meeting was held with two experts. As a result of analysis, it was found that Teachers of Turkish as a foreign language online form seven categories: culture, difficult, enjoyable, innovation, labor, food and other. It was noted that the participants mostly created metaphors in the culture category.

Keywords: Teaching Turkish as a foreign language online, Teachers of Turkish as a foreign language, metaphor, qualitative method

\section{Giriş}

Çin’in Wuhan Kenti’nde 2019 yılının sonunda görülen ve 2020 yılında tüm dünyayı yayılan Covid-19 salgını neredeyse tüm sektörleri etkilemiştir. Salgın sürecinde, eğitim alanına bakıldığında, yüz yüze eğitimden uzaktan eğitime ani bir geçiş yapıldığı görülmektedir. Uzaktan eğitimle derslerin yürütülebilmeye başlamasıyla alt yapı sorunu, ilgili teknolojik araç-gereçlerin temin edilmiş olmaması gibi başlıca sorunlar kendini göstermiştir. Çünkü tüm dünya ve Türkiye bu beklenmedik sürece hazırlıksız yakalandığından binlerce öğretmen ve milyonlarca öğrencinin eş zamanlı olarak teknolojiye erişimlerini ve teknoloji okuryazarlıklarını bir anda sağlamanın mümkün olmamıştır. Dijital çağ olarak bilinen 21. yüzyılda, beklenmedik olaylar karşısında, eğitim sistemlerinin b planı olarak uzaktan eğitimine geçiş yapabilecek bir yapıda olması gerektiğini süreç insanlara göstermiştir. Çünkü 2020 yılında neredeyse tüm eğitim kademelerinin başvurduğu uzak eğitim yeni bir sistem değildir. Uzaktan eğitimin tarihine bakıldığında 1833'te bir İsveç gazetesinde posta (mektup) yoluyla kompozisyon dersi verileceği ilanı ile gün yüzüne çıktığı ve 1840 yılına gelindiğinde İngiltere'de Isaac Pitman'ın yazışma yoluyla stenografi öğretimine izin verilmesiyle uzaktan eğitimin ilk uygulamasının gerçekleştiği görülmektedir (Simonson, Smaldino ve Zvacek, 2015). Türkiye'de ilk kez 1924 yllında John Dewey uzaktan eğitimi teklif etse de 1927 yılında dönemin bakanı ile yapılan toplantıda Türkiye'nin \%9o'ınn okur yazar olmamasından dolayı uygulamaya geçilmemiştir. 1950'li yıllara gelindiğinde Ankara Üniversitesi Hukuk Fakültesi Banka ve Ticaret Hukuku Araştırma Enstitüsü’nde banka çalışanlarına yönelik verilen kısa süreli mektupla hizmet içi verilen eğitim, Türkiye'deki ilk uzaktan eğitim uygulaması olarak tarihteki yerini almıştır (Aydın, 2011; Çallı, İşman ve Torkul, 2001). O dönemlerde okulların yükseköğretimdeki artan talebi karşılayamaması nedeniyle bazı mesleki konularda mektupla eğitim verilmesi amacıyla 1961 yılında Millî Eğitim Bakanlığı bünyesinde Mektupla Öğretim Merkezi, ileriki yıllarda Deneme Yüksek Öğretmen Okulu ve Yaygın Yüksek Öğretim Kurumu (YAYKUR) kurulmuştur (Aydın, 2011; Çallı, İşman ve Torkul, 2001). Türkiyede ilk uzak eğitim uygulamaları uzun soluklu olmasa da Anadolu Üniversitesi, Açıöğretim Fakültesi bünyesinde İktisat ve İşletme lisans programları ile 1982-1983 öğretim yılında açık ve uzaktan öğrenme uygulamalarına başlamasıyla Türkiye'de bu alanda önemli bir adım atılmıştır.

$\mathrm{Bu}$ çalışmada başvurulan metafor terimi incelendiğinde ise bireyin kendi dünyasını anlamasına ve yapılandırmasına yönelik zihinsel haritalar ve modeller belirlemesi (Arslan ve Bayrakcı, 2006) olarak

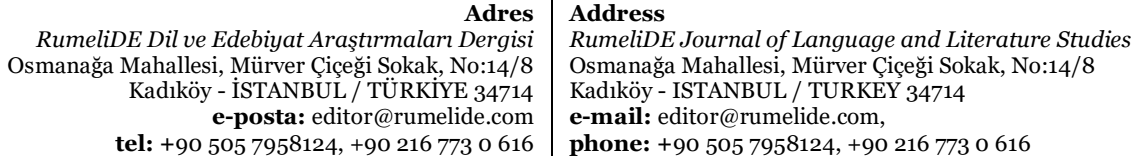


literatürde kendini gösterdiği bununla birlikte eğitim bilimleri alanında ise kavramların analiz edilmesinde, hayatın daha anlaşılır bir duruma getirilmesinde, tecrübelerin aktarılmasında, duygu ve düşüncelerin paylaşılmasında, bireyin bir nesne, kavram veya olguya dair algılarının belirlenmesinde kullanıldığı (Aykaç ve Çelik, 2014) şeklinde yer aldığı görülmüştür. Daha kısa tanımıyla ise metafor iki benzeşmez olgu arasında ilişki kurmaya yardım edendir (Saban, 2008).

Türkiye'de Yabancılara Türkçe öğreten kurumların neredeyse tamamı koronavirüs sonrası diğer eğitim kademleri gibi uzaktan eğitime geçiş yapmıştır. Covid-19 salgını öncesi uzaktan eğitimle derslerin yüz yüze yürütülmesinden dolayı yabancılara uzaktan Türkçe öğretim çalışmaları sınırlı iken 2020 yll itibariyle diğer alanlarda olduğu gibi bu alandaki çalışmalar da hız kazanmıştır. Başlıca çalışma konularına bakıldığında Türkçenin yabancı dil olarak uzaktan öğretimine ilişkin öğrenici ve öğretici görüşleri (Güngör, Çangal ve Demir, 2020; Karatay, Kaya ve Başer, 2021; Yurdakul ve Duman, 2021), yabancı dil olarak Türkçe öğrenme sistemlerinin eş zamansız iletişim ortamlarındaki yeri (Pilancı, 2018) dikkat çekmektedir. Uzaktan eğitimle ilgili yapılan diğer çalışmalara bakıldığında, öğretmen adaylarının ve öğrencilerin uzaktan eğitime yönelik algıları ve görüşleri (Bozkurt, 2020; Kaplan ve Gülden, 2021; Karakuş, Ucuzsatar, Karacaoğlu, Esendemir ve Bayraktar, 2020; Karatepe, Küçükgençay ve Peker, 2020; Özgül, Ceran ve Yıldız, 2020; Sarıtaş ve Barutçu, 2020; Yılmaz ve Güven, 2015) ve Türkçe uzaktan eğitim araştırmalarının incelenmesi (Horzum, Özkaya, Demirci ve Alpaslan, 2013) dikkat çekmektedir. Türk dilini ve kültürünü dünyaya tanıtmaya çalışan öğreticilerin salgın sürecinde uzaktan eğitimi nasıl algıladıkları merak konusu olmuştur. Çünkü Türk dilinin ve kültürünün dünyadaki hak ettiği değeri görmesi ve yaygınlaşması için mücadele eden yabancılara Türkçe öğreticilerin ne sorunlar yaşadığını tespit etmek ve çözüm yolları aramak gerekmektedir. Buna bağlı olarak da alanyazında yabancı dil olarak Türkçeyi uzaktan öğreten Türkçe öğreticilerinin uzaktan eğitimle ilgili metaforik algılarını ortaya çıkaran bir çalışmaya rastlanılmadığından bu araştırmanı amacı yabancı dil olarak Türkçeyi uzaktan öğretenlerin uzaktan öğretime ilişkin metaforik algılarını ortaya çıkarmaktır.

\section{Yöntem}

$\mathrm{Bu}$ araştırmada, nitel araştırma yöntemlerinden olgu bilim (fenomenoloji) kullanılmıştır. Olgu bilim, farkında olunulan fakat derinlemesine ve ayrıntılı bir anlayışa sahip olunmayan olgulara odaklanmakta ve olgular, yaşadığımız dünyada olaylar, deneyimler, algılar, yönelimler, kavramlar ve durumlar gibi farklı biçimlerde ortaya çıkmaktadır (Yıldırım ve Şimşek, 2013). Dolayısıyla yabancı dil olarak Türkçeyi uzaktan öğretenlerin uzaktan öğretimle ilgili yaşadıkları olay, durum, algı ve deneyimleri nitel araştırma yöntemlerinden olgu bilim ile ortaya çıkarmak amaçlanmıştır.

\section{Çalışma grubu}

Bu araştırmanın çalışma grubu, 2020-2021 eğitim-öğretim yllının bahar döneminde Türkiye'nin farklı illerinde yabancılara Türkçe öğreten 90 (61 kadın, 29 erkek) katılımcıdan oluşmaktadır. Ancak 7 katılımcı (4 erkek, 3 kadın) kişisel bilgilerini doldurmasına rağmen metafor bölümünü boş bıraktığından çalışmadan çıkarılmıştır. Çalışmada 58 kadın, 25 erkek toplam 83 katılımcı yer almıştır.

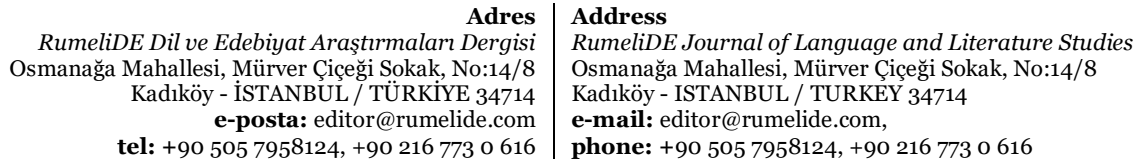

RumeliDE Dil ve Edebiyat Araşttrmalar Dergis

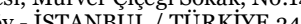
el: +90 $5057958124,+902167730616$ 
Tablo 1. Çalışmana grubuna ait demografik bilgiler-1

\begin{tabular}{llll}
\hline & Çalsştı̆̆ kurumdan & Kişisel & Toplam \\
\hline Ders verilen teknolojik aracı temin şekli & 15 & 68 & 83 \\
Ders esnasında internet erişimi & 9 & 74 & 83 \\
\hline
\end{tabular}

Tablo 1'e bakıldı̆̆ı zaman katılımcıların çoğunluğunun uzaktan yabancılara Türkçe öğretimi sürecinde ders verilen teknolojik aracı ve interneti kişisel olarak temin ettiği görülmektedir. Salgın sürecinde Türkiye'de uygulanan esnek çalışma saatlerinin öğreticilerin evden derslerini yürüttüklerinin kişisel temine etki ettiği söylenebilir. Bununla birlikte 9 katılımcının kurumdan teknolojik araç temin etmesine rağmen interneti kişisel temin ettiği, bir katılımcının da kişisel teknolojik aracı olmasına rağmen çalıştığı kurumdan interneti temin ettiği de fark edilmiştir.

Tablo 2. Çahşmana grubuna ait demografik bilgiler-2

\begin{tabular}{l|l}
\hline Görev süresi & Siklık \\
\hline $1-3$ yll & 52 \\
$4-9$ yll & 22 \\
$10+$ yll & 9 \\
Toplam & 83 \\
\hline
\end{tabular}

Tablo 2'ye bakıldığında katılımcıların görev süresinin en çok 1-3 yıl çalışan katılımcılardan oluştuğu görülmektedir. Yabancılara Türkçe öğreten kurumların tarihinin çok eski olmamasıyla ve bu alanın kurumsal olarak çok eskiye dayanmamasıyla ilgili olduğu söylenebilir. Ayrıca, 10+ yıl çalışan katılımcıların 35+ yaşında olduğu, 4-9 yıl çalışan katılımcıların çoğunluğunun 28-34 yaş aralığında olduğu ve 1-3 yıl çalışan katılımcıların çoğunluğunun da 20-27 yaş aralı̆̆ında olduğu fark edilmiştir.

\section{Veri toplama aracı}

$\mathrm{Bu}$ araştırmanın veri toplama aracı, yabancılara Türkçe öğreticileri için hazırlanan metafor formundan oluşmaktadır. Araştırmanın verileri, yabancılara uzaktan Türkçe öğretenlerin uzaktan öğretime ilişkin oluşturdukları metaforlardır. Metaforlar, insanın doğayı ve çevreyi anlamasını, anlamsız gibi görünen nesnel gerçeklikten belirli yorumlar yoluyla anlamlar çıkarmasını, yaşantı ve deneyime anlam kazandırmanın araçları olarak bilinmektedir (Yıldırım ve Şimşek, 2013).

Verilerin toplanması için oluşturulan metafor formunda, yönerge kısmı, demografik bilgiler kısmı ve metafor kısmı bulunmaktadır. Yönerge kısmında, çalışmanın amacı belirtilip paylaşılan bilgilerin gizli kalacağı, çalışma sonucunu merak edenler için mail adresi bulunmaktadır. Demografik bilgiler kısmında, katılımcılara ait cinsiyet, yaş, görev yeri görev süresi, ders verilen teknolojik aracın ve internetin temin şekli gibi bilgiler yer almaktadır. Metafor kısmında ise "Yabancılara uzaktan Türkçe öğretmek gibidir. Çünkü ." ifadesini benzetme yaparak doldurmaları istenmiştir.

\section{Verilerin toplanması ve analizi}

Araştırma verilerini toplamak için GoogleDocs'tan yararlanılmıştır. Google Dokümanlar-Formlar sekmesinden boş bir forma yönerge, kişisel bilgiler ve metafor bölümleri yazılmış ve katılımcılarla form linki paylaşılmış ve katılımcılardan formu doldurmaları istenmiştir. Böylece araştırmanın verileri

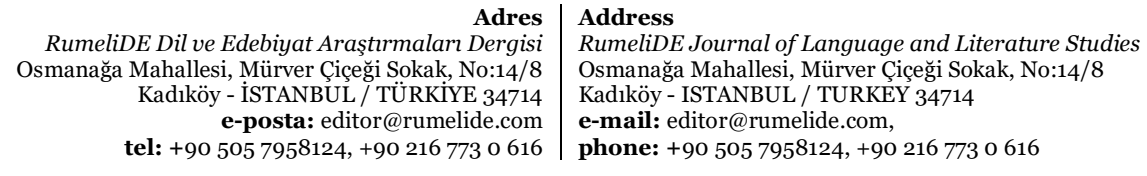


toplanmıştır. Veriler excel programına otomatik aktarıldıktan sonra araştırma için oluşturulan dosyaya kaydedilmiştir.

$\mathrm{Bu}$ araştırmada, içerik analizi kullanılmıştır. İçerik analizinde temel amaç, elde edilen verileri açılayabilecek kavramlara ve ilişkilere ulaşmak, benzer verileri belli kavramlar ve temalar çerçevesinde bir araya getirmek ve bunları anlaşılabilir olacak şekilde düzenleyerek yorumlamaktır (Ylldırım ve Şimşek, 2013). Bu doğrultuda katılımcıların oluşturdukları metaforlar incelenmiş, ortak özelliklere sahip metaforlar belirlenip sınıflandırılmıştır. Excelden word dosyasına veriler aktarılırken kategorilere ayrılmış, ortak özellikte olanlar bir araya getirilerek tablolaştırılmıştır.

\section{Geçerlik ve güvenirlik}

Nitel araştırmalarda geçerlik ve güvenirliği sağlama yollarından biri uzman görüşü almaktadır. Yıldırım ve Şimşek (2013)'e göre uzman incelemesi iki şekilde yapılmaktadır. Birincisi araştırmacı ve uzmanın birlikte değerlendirme toplantısı yapması, ikincisi de araştırmacının elde ettiği tüm dokümanları ham haliyle bir uzmana göndermesidir. Bu araştırmada, araştırmacılar önce kendileri toplantı yapıp kategorileri oluşturmuş daha sonra da iki uzmanla değerlendirme toplantısı yapmışlardır. Araştırmacılar, sözel olarak süreci ve sonuçları uzmanlarla paylaşmışlar ve metaforların sınıflandırılmasında uzmanların görüşlerini almışlardır. Toplantı sürecinde, araştırmacılar, uzmanların süreçle ilgili sorularını cevaplamışlardır.

\section{Bulgular}

Yabancılara Türkçe öğretenlerin uzaktan öğretime ilişkin oluşturdukları metaforlar ortak özelliklerine göre sınıflanmıştır. Bu doğrultuda kültür, zor, keyifli, yenilik, emek, yemek ve diğer olmak üzere yedi kategori oluşmuştur. Oluşturulan kategorilere ait metaforlar ve başlıca örnekleri aşağıda tablolar şeklinde verilmiştir.

\section{Kültür kategorisine ait metaforlara ait bulgular}

Yabancılara uzaktan Türkçe öğretenlerin uzaktan öğretime ilişkin kültür kategorisinde oluşturdukları metaforlar Tablo 3’te yer almaktadır.

Tablo 3. Kültür kategorisine ait metaforlar

\begin{tabular}{|c|c|}
\hline Metafor & Sıklık \\
\hline Kültür elçiliği & 2 \\
\hline Maneviyatı maddiyata dönüştüren bir araç & 2 \\
\hline Kültürel etkileşim & 1 \\
\hline Kültürel paylaşım & 1 \\
\hline Dil köprüsü kurmak & 1 \\
\hline Kültür tanıtmak & 1 \\
\hline Kültür sevdirmek & 1 \\
\hline Tüm dünyayı elinde Türk bayrağı ile dolaşmak & 1 \\
\hline Milli görev & 1 \\
\hline Vatanperverlik & 1 \\
\hline Milli gurur & 1 \\
\hline $\begin{array}{r}\text { Adres } \\
\text { RumeliDE Dil ve Edebiyat Arasstrmalarar Dergisi } \\
\text { Osmanağa Mahallesi, Mürver Ciçeği Sokak, No:14/8 } \\
\text { Kadıköy - ISTANBUL / TÜRKIYE } 34714 \\
\text { e-posta: editor@rumelide.com } \\
\text { tel: }+90 \text { 505 7958124, +90 216 773 o } 616\end{array}$ & $\begin{array}{l}\text { Address } \\
\text { RumeliDE Journal of Language and Literature Studies } \\
\text { Osmanağa Mahallesi, Mürver Cicceği Sokak, No:14/8 } \\
\text { Kadıköy - ISTANBUL / TURKEY } 34714 \\
\text { e-mail: editor@rumelide.com, } \\
\text { phone: +90 505 7958124, +90 } 216773 \text { o } 616\end{array}$ \\
\hline
\end{tabular}




\begin{tabular}{ll} 
Vatan görevi & 1 \\
Askerlik & 1 \\
Turist rehberliği & 1 \\
Tanışmak & 1 \\
Dünyanın nabzını tutmak & 1 \\
Yeni bir dost kazanmak & 1 \\
Orda bir köy var uzakta şarkısı & 1 \\
Şifa & 1 \\
Sevda & 1 \\
Sevgi & 1 \\
Ülkü & 1 \\
Evimizden tüm dünyaya ulaşabilmek & 1 \\
Dünyaya bakacakları yeni bir pencere açmak & 1 \\
Maliyeti düşük bir tohumdan çlkan meyvelerin kâra dönüşmesi & 1 \\
Mucize & 1 \\
Toplam & 1 \\
\hline
\end{tabular}

Tablo 3'e bakıldığında yabancılara uzaktan Türkçe öğretenlerin uzaktan öğretime ilişkin kültür kategorisinde oluşturdukları metaforlar görülmektedir. Kültür kategorisine ait toplam 26 farklı metaforun oluştuğu görülmektedir. Bu kategoride oluşturulan metaforların ortak özelliği Türk dilinin tanınması, kültür aktarımı, farklı kültürle etkileşim kurma, uluslararasılaşma olarak dikkat çekmektedir. Bu çalışma kapsamında oluşturulan kategorilerde en çok kültür kategorisinde metafor oluşturdukları fark edilmiştir.

K14 "Yabancllara uzaktan Türkçe öğretmek türlü zorluklara rağmen bir dil köprüsü kurmak gibidir. Yüz yüze öğretim elbette daha sağllkh ve etkileşimlidir ancak önemli olan Türkçeyi sevdirmek ve öğrencilerimizin bu konuda varsa olumsuz ön yargılarmı önüne geçmektir. Sevgiyle birlikte öğrenim zaten kendiliğinden gelecektir.”

K5o "Yabancılara uzaktan Türkçe öğretmek kültür elçiliği gibidir. Çünkü Türk dilini yabancılara öğretirken bu paylaşım içinde Türk kültürünü, coğrafyasını, tarihi değerlerini ve sosyal hayatını da, dünyadaki pek çok insana, gösterme imkanı bulabilmekteyiz.”

K89 "Yabancılara Türkçe öğretmek Tüm dünyayı elinde Türk bayrağı ile dolaşmak gibidir. Çünkü Yabancılara Türkçe öğretirken hem dünyanın birçok ülkesinden insan tanımakta hem ülkelerin kültürlerini öğrenmekte hem de Türk Kültürünü tüm dünyaya aktarmaktayız. Sadece dil Öğretimi değil kültür etkileşimi de gerçekleşmektedir."

\section{Zor kategorisine ait metaforlara ait bulgular}

Yabancılara uzaktan Türkçe öğretenlerin uzaktan öğretime ilişkin zor kategorisinde oluşturdukları metaforlar Tablo 4’te yer almaktadır.

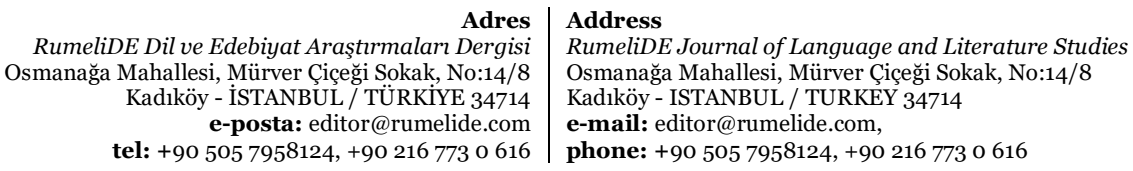


Tablo 4. Zor kategorisine ait metaforlar

\begin{tabular}{ll}
\hline Metafor & Sılklk \\
\hline Zor & 2 \\
Birine telefonla tarif ederek iş yaptırmak & 2 \\
Çatalla çorba içmeye çalışmak & 1 \\
Sabır taşı & 1 \\
Görmeyen birine resim anlatmak & 1 \\
Deveye hendek atlatmak & 1 \\
Camdan komşuya seslenmek & 1 \\
Uzaktan uzağa bir köyü tanımaya çalışmak & 1 \\
Fanusun içinden sesini duyurmaya çalışmak & 1 \\
Tiyatro gösterisini televizyondan izlemek & 1 \\
Soğan doğramak & 1 \\
Kaynayan sütü içmek & 1 \\
Seminer vermek & 1 \\
Radyo tiyatrosu yapmak & 1 \\
Uzaktan sevmek & 1 \\
Toplam & 1 \\
\hline
\end{tabular}

Tablo 4’e bakıldığında yabancılara uzaktan Türkçe öğretenlerin uzaktan öğretime ilişkin zor kategorisinde oluşturdukları metaforlar görülmektedir. Zor kategorisine ait toplam 15 farklı metaforun oluştuğu görülmektedir. Bu kategoride oluşturulan metaforların ortak özelliği Yabancılara uzaktan Türkçe öğreticilerinin bu öğretim şeklini zor ve süreçte eksik bir noktanın olması olarak değerlendirmeleridir. Özellikle etkileşim eksikliği, teknik aksaklıklar, motivasyon problemi gibi sorunlar üzerinde durdukları fark edilmiştir.

K51 "Yabancllara uzaktan Türkçe öğretmek camdan komşuya seslenmek gibidir sesini duyurmak ve amacına ulaşmak için daha çok çaba harcamak gerekir. Çünkü mesafeler iletişimi zorlaştırır."

K57 "Yabancllara uzaktan Türkçe öğretmek uzaktan sevmek gibidir. Çünkü insan canl canl öğrencilerini yaninda görmek ister, sinıfinda o ders atmosferini yaşamak ister. Hep bir özlem vardır, bu duruma alışma çabası ile tüm sevgisini ifade etmenin farkl yolların ararken bulur kendisini. Hayatın akışında hem çok yakınsın hem çok uzaksın hissinin birleşimi bir duygu."

K68 "Yabancllara uzaktan Türkçe öğretmek uzaktan uzağa bir köyü tanımaya çalşmak gibidir. Toprağına ayak basmadan bir köyü tanımak nasıl olası değilse bir dili de yeterli ölçüde konuşmadan özümseyebilmek çok güçtür. (Orda bir dil var uzakta.. Doya doya konuşamazsak da...)”

\section{Keyifli kategorisine ait metaforlara ait bulgular}

Yabancılara uzaktan Türkçe öğretenlerin uzaktan öğretime ilişkin keyifli kategorisinde oluşturdukları metaforlar Tablo 5'te yer almaktadır.

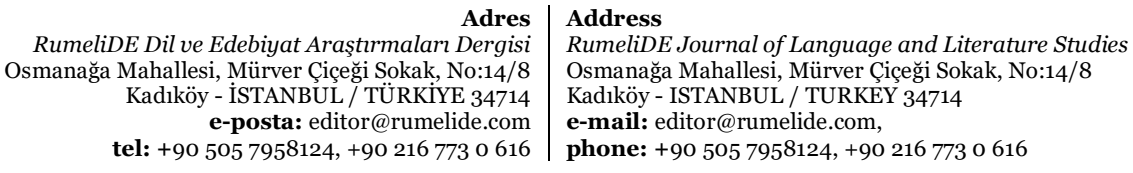


Tablo 5. Keyifli kategorisine ait metaforlar

\begin{tabular}{ll}
\hline Metafor & Siklık \\
\hline Eğlenceli & 2 \\
Keyifli & 1 \\
Kolay & 1 \\
Pratik & 1 \\
Şïr & 1 \\
Bütün gün diyar diyar gezip arı gibi bal yapmak & 1 \\
Yüz yüze öğretmek & 1 \\
Dilsiz biriyle işaret diliyle anlaşmak & 1 \\
Çocukla oyun oynamak & 1 \\
Oyun & 1 \\
Toplam & 1 \\
\hline
\end{tabular}

Tablo 5’e bakıldığında yabancılara uzaktan Türkçe öğretenlerin uzaktan öğretime ilişkin keyifli kategorisinde oluşturdukları metaforlar görülmektedir. Keyifli kategorisine ait toplam 10 farklı metaforun oluştuğu görülmektedir. Bu kategoride oluşturulan metaforların ortak özelliği öğreticilerin Yabancılara uzaktan Türkçe öğretmeyi kolay, pratik, eğlenceli bulmasıdır.

K38 "Yabancılara uzaktan Türkçe öğretmek bir çocukla oyun oynamak gibidir. Çünkü tıpkı bir çocuğun oyun esnasında öğrenmesi ve aynı zamanda eğlenmesi gibidir.”

K66 "Yabancllara uzaktan Türkçe öğretmek oyun gibidir. Çünkü işlevsel olarak öğrenmenin temelinde eğlenmek olmahdır. Dil öğretimi ve öğrenimi her ne kadar büyük emek istese de dersleri bir nevi eğitsel oyuna dönüştürmek, bazen tiyatral bir biçime sokmak oldukça kazanım sağlayacak bir durumdur. Bazen uzaktan eğitim de, derslerde bir simı ortamında anlk bulunamayacak materyallere sahip olunabiliyor. Bu da öğrenimde ki başarmm artmasma neden oluyor. Ben birçok nedenden uzaktan eğitim ile dil öğretiminim yaygınlaşacağına inanıyorum.”

\section{Yenilik kategorisine ait metaforlara ait bulgular}

Yabancılara uzaktan Türkçe öğretenlerin uzaktan öğretime ilişkin yenilik kategorisinde oluşturdukları metaforlar Tablo 6'da yer almaktadır.

Tablo 6. Yenilik kategorisine ait metaforlar

\begin{tabular}{|c|c|}
\hline Metafor & Sıklık \\
\hline Bebek büyütmek & 3 \\
\hline Bir çocuğa okuma yazma öğretmek & 1 \\
\hline Bir bebeğe konuşmayı öğretmek & 1 \\
\hline Daha önce hiç yüzmediğiniz bir koyda yüzmek & 1 \\
\hline Hiç uğramadığım bir gökyüzünde bulut olmak & 1 \\
\hline Dil keşfetmek & 1 \\
\hline Yeni tecrübeler & 1 \\
\hline Yeni bir mesleğe başlamak & 1 \\
\hline $\begin{array}{r}\text { Adres } \\
\text { RumeliDE Dil ve Edebiyat Araştrrmaları Dergisi } \\
\text { Osmanağa Mahallesi, Mürver Ciçeği Sokak, No:14/8 } \\
\text { Kadıköy - İSTANBUL / TÜRKIYY } 34714 \\
\text { e-posta: editor@rumelide.com } \\
\text { tel: +90 505 7958124, +90 216 } 7730616\end{array}$ & $\begin{array}{l}\text { Address } \\
\text { RumeliDE Journal of Language and Literature Studies } \\
\text { Osmanağa Mahallesi, Mürver Ciçeği Sokak, No:14/8 } \\
\text { Kadıköy - ISTANBUL/ TURKEY } 34714 \\
\text { e-mail: editor@rumelide.com, } \\
\text { phone: +90 505 7958124, +90 } 216773 \text { o } 616\end{array}$ \\
\hline
\end{tabular}


Tablo 6’ya bakıldı̆̆ında yabancılara uzaktan Türkçe öğretenlerin uzaktan öğretime ilişkin yenilik kategorisinde oluşturdukları metaforlar görülmektedir. Yenilik kategorisine ait toplam 9 farklı metaforun oluştuğu görülmektedir. Bu kategoride oluşturulan metaforların ortak özelliği öğreticilerin Yabancılara uzaktan Türkçe öğretmeyi yeni bir dil ve kültür öğretimi olarak değerlendirmesidir. Öğreticilerin yabancılara uzaktan Türkçe öğretiminde yenilik olarak teknolojik bir yenilikten ziyade yabancılara yeni bir dil ve kültür olarak Türkçeyi öğrenmelerini değerlendirdikleri fark edilmiştir.

K7o "Yabancılara uzaktan Türkçe öğretmek, konuşmayı bilmeyen bir bebeğe konuşmayı öğretmek gibidir. Çünkü her yeni dil gibi Türkçe de bu köprü olma görevine başvurur.”

K81 "Yeni okuma yazma öğrenen bir çocuğa okuma yazma öğretmek gibi. Çünkü öğrenmek için son derece motiveler ve ellerinden geleni yapıyorlar."

\section{Emek kategorisine ait metaforlara ait bulgular}

Yabancılara uzaktan Türkçe öğretenlerin uzaktan öğretime ilişkin emek kategorisinde oluşturdukları metaforlar Tablo 7'de yer almaktadır.

Tablo 7. Emek Kategorisine Ait Metaforlar

\begin{tabular}{ll}
\hline Metafor & S1klık \\
\hline Öğrenci olmak & 2 \\
Emek & 1 \\
Ağaç olmak & 1 \\
Havanın birden değişmesi & 1 \\
Mobilya kurmak & 1 \\
Bina inşa etmek & 1 \\
Halata düğüm atmak & 1 \\
Toplam & 8 \\
\hline
\end{tabular}

Tablo 7’ye bakıldığında yabancılara uzaktan Türkçe öğretenlerin uzaktan öğretime ilişkin emek kategorisinde oluşturdukları metaforlar görülmektedir. Emek kategorisine ait toplam 7 farklı metaforun oluştuğu görülmektedir. Bu kategoride oluşturulan metaforların ortak özelliği öğreticilerin Yabancılara uzaktan Türkçe öğretmeyi ön hazırlık gerektiren, zaman ayırmayı ve emek harcamayı gerektiren bir süreç olarak değerlendirmeleridir.

K18 “Yabancllara uzaktan Türkçe öğretmek yeniden öğrenci olmak gibidir. Çünkü ön hazırlık ve emek ister :)"

K26 "Yabancllara uzaktan Türkçe öğretmek ağaç olmak gibidir. Çünkü dünyanın her yerine dallanırız ulaşır. Zamanla, emekle o ağacın meyvelerini alırsını.”

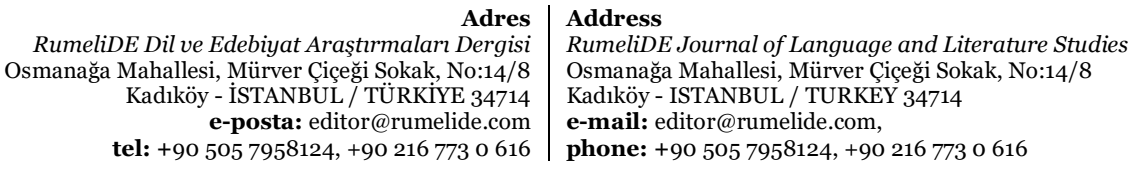




\section{Yemek kategorisine ait metaforlara ait bulgular}

Yabancllara uzaktan Türkçe öğretenlerin uzaktan öğretime ilişkin yemek kategorisinde oluşturdukları metaforlar Tablo 8'de yer almaktadır.

Tablo 8. Emek kategorisine ait metaforlar

\begin{tabular}{ll}
\hline Metafor & S1klık \\
\hline Şekersiz baklava & 1 \\
Ekşi üzüm yemek & 1 \\
Yemek sipariş etmek & 1 \\
Şekersiz sakız çiğnemek & 1 \\
Şehriyesiz pilav & 1 \\
Yapay çiçek & 1 \\
Toplam & 6 \\
\hline
\end{tabular}

Tablo 8'e bakıldığında yabancılara uzaktan Türkçe öğretenlerin uzaktan öğretime ilişkin yemek kategorisinde oluşturdukları metaforlar görülmektedir. Yemek kategorisine ait toplam 6 farklı metaforun oluştuğu görülmektedir. Bu kategoride oluşturulan metaforların ortak özelliği öğreticilerin Yabancılara uzaktan Türkçe öğretmeyi lezzetli bir yiyecekte eksik olan bir şeyden dolayı lezzetsiz bulmalarıyla ilgilidir. Eksik bulunan özelliği de etkileşim olarak ifade etmişlerdir.

K19 "Yabancllara uzaktan Türkçe öğretmek, şekersiz bir baklava gibidir. Çünkü, eğitimin tadı öğrenciye mecazi olarak dokunabilmek, görebilmek ve onu hissedebilmekten geçer. Uzaktan bunu sağlamak çok mümkün olmuyor.”

K37 "Paket servisten yemek söylemek gibidir. Çünkü teknolojiktir, pratiktir, ulaşllabilirdir, ihtiyacı karşılar, güzeldir ama anne yemeğinin yerini tutmaz.”

\section{Diğer kategorisine ait metaforlara ait bulgular}

Yabancllara uzaktan Türkçe öğretenlerin uzaktan öğretime ilişkin diğer kategorisinde oluşturdukları metaforlar Tablo g'da yer almaktadır.

\section{Tablo 9. Diğer Kategorisine Ait Metaforlar}

\begin{tabular}{ll}
\hline Metafor & Sıklık \\
\hline Körebe oynamak & 1 \\
Açık bilet & 1 \\
Bisiklete binmek & 1 \\
Seyahat esnasında radyoda çalan bir müziğe verdiğimiz tepki & 1 \\
Heybedeki yükü hafifletmek & 1 \\
Ayna & 1 \\
Kaynayan sütü içmek & 1 \\
Toplam & 7 \\
\hline
\end{tabular}

\footnotetext{
Adres $\mid$ Address

RumeliDE Dil ve Edebiyat Araştırmaları Dergisi Osmanağa Mahallesi, Mürver Çiçeği Sokak, No:14/8 Kadıköy - İSTANBUL / TÜRKIYE 34714 e-posta: editor@rumelide.com

RumeliDE Journal of Language and Literature Studies Osmanağa Mahallesi, Mürver Çiçeği Sokak, No:14/8

Kadıköy - ISTANBUL / TURKEY 34714

e-mail: editor@rumelide.com, tel: +90 505 7958124, +90 216773 o 616 phone: +90 505 7958124, +90 2167730616
} 
Tablo 9'a bakıldığında yabancılara uzaktan Türkçe öğretenlerin uzaktan öğretime ilişkin diğer kategorisinde oluşturdukları metaforlar görülmektedir. Diğer kategorisine ait toplam 7 farklı metaforun oluştuğu görülmektedir. Bu kategoride oluşturulan metaforların körebe oynamak ile bir eksiklik olsa da diğer becerilerle kapatmaya çalışma, açık bilet ile esneklik, bisiklete binmek ile çoklu beceri, seyahat esnasında radyoda çalan bir müziğe verdiğimiz tepki ile fayda, heybedeki yükü hafifletmek ile paylaşma, ayna ile öz değerlendirme ve kaynayan sütü içmek ile acemiliği atıp sürece adapte olma ifade edilmiştir.

K45 "Yabancılara uzaktan Türkçe öğretmek kaynayan sütü içmek gibidir. Çünkü sürecin başında acemisi olduğumuz çevrim içi Türkçe derslerinde yanarak yanılarak deneyerek tecrübe ederek bir yılın sonunda anca dilimizin yanı̆̆ geçirdik ve sütü nasıl içeceğimizi öğrendik. Yüz yüze eğitimlerde aşağı yukarı ne yapacağın bellidir. Öğrenciyle bire bir etkileşim hâlinde olmak verimi artırı yapabileceklerimizi daha da zenginleştirebilecekken çevrim içi derslerde elinin kolunun bağlı olduğunu hissettiğ in zamanlar olabiliyor. Üstesinden gelinemeyecek problem değildi hiçbir zaman. Dediğim sadece acemiydik çevrim içi derslerde. Artık yavaş yavaş sütü nasıl içeceğimizi öğrendik.”

K62 "Yabancllara uzaktan Türkçe öğretmek heybemdeki yükü hafifletmektir. Teorik olarak aldiğım bilgilerin üzerimdeki ağırlığı ancak paylaştıkça, uygulamaya koydukça hafifletebiliyorum. Böylece Kazan-Kazan tekniği ile hem gelişen teknolojiyi yakundan takip ederek alanımda kendimi geliştiriyorum hem de öğrenicilerime katkıda bulunuyorum. Bilgilerimi aktif olarak kullanabilmek, uygulamaya koyabilmek bana kendimi geliştirme ve Türk dilini yayma firsatı sunuyor.”

\section{Sonuç ve tartışma}

Bu araştırmada 2019 ylının sonunda Çin'in Wuhan Kenti’nde ortaya çıkan ve 2020 yllında tüm dünyaya yayılan Covid-19 salgını nedeniyle 2020-2021 eğitim döneminde uzaktan eğitime geçen Türkiye'de, yabancılara uzaktan Türkçe öğretenlerin uzaktan öğretime ilişkin algıları araştırılmış ve 7 metafor kategorisi (kültür, zor, keyifli, yenilik, emek, yemek ve diğer) ortaya çıkmıştır. Yabancılara uzaktan Türkçe öğretenlerin uzaktan öğretime ilişkin oluşturdukları metaforlara bakıldığında en çok kültür kategorisinde metafor oluşturdukları görülmektedir. Katılımcıların en çok kültür kategorisinde metafor oluşturmasının Tapan (1990)'ın da ifade ettiği gibi yabancı bir dil öğrenmenin aynı zamanda yabancı bir kültürü de anlamaya ve tanımaya çalışmakla ilgili olduğu söylenebilir. İkinci bir dil veya yabancı bir dil öğrenmek o dilin konuşulduğu toplum hakkında bilgi sahibi olma ve o dile ait kültürü tanıma firsatı da verdiğinden (Demircan, 2002: Melanlığlu, 2013) dil ile ilgili bir çalışmada kültürün çağrışım yapması olağandır. Çünkü bir dil öğrenilirken o coğrafyadaki insanların günlük hayatlarında neler yaptıkları, olaylara karşı gösterdikleri tepkileri, gelenek ve görenekleri, tarihi gibi birçok unsur da beraberinde öğrenilir (Mutlu, 2020). Kısaca kültür ve dil öğretimi birbirini destekleyen bir döngü içerisinde olduğundan (Okur, 2013; Okur ve Keskin, 2013), kültür kategorisinde en çok metafor oluşturulması beklenen bir sonuç olmuştur. Kültür ve dil ilişkisinin parçalanmaz bütünlüğü karşısında oluşturulan metaforların yabancılara uzaktan Türkçe öğretmekten ziyade yabancılara Türkçe öğretmek ile bağlantılı olduğu da tespit edilmiştir.

Kültür kategorisinden sonra zor ve yemek kategorilerinin toplamı (toplam 23 metafor) en çok oluşturulan metafor kategorileri olmuştur. Zor kategorisinde öğreticilerinin yabancılara uzaktan Türkçe öğretimini zor bulmanın yanı sıra eksik kalan bir noktanın olduğuna vurgu yapmaları, yemek kategorisiyle ortak özelliğe sahip olduğunu göstermektedir. Bu iki kategorinin Türkiye'nin salgın nedeniyle ani bir kararla yüz yüze eğitimden uzaktan eğitime geçiş yapmasıyla bu iki kategorinin oluşturulduğu söylenebilir. Çünkü 2020 yllında Türkiye'de uzaktan eğitimle yaşanan gerekli alt yapının

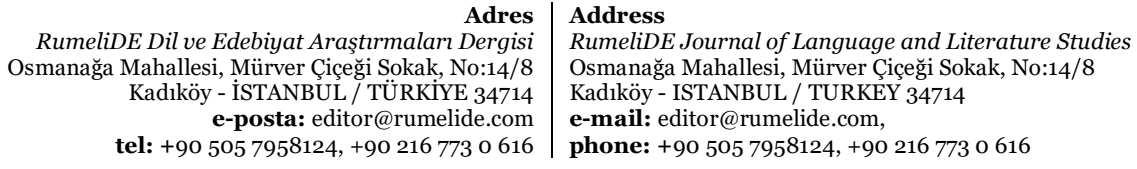


olmaması sorunu yaşanan bu süreçte eksik kalan bir şeylerin olduğunu ifade eden katılımcı görüşleriyle örtüşmektedir. Alanyazında salgın sürecinde yapılan başlıca çalışmalara bakıldığında da alt yapı eksikliklerinin olduğu (Bayburtlu, 2020; Tümen Akyldız, 2020), öğretim elemanlarının uzaktan eğitime hazır olma durumda tereddütlerinin olduğu (Durak, Çankaya ve İzmirli, 2020) tespit edilmiştir. Katılımcıların salgın sürecinde uzaktan eğitimi zor ve eksik bir noktaya sahip bir sistem olarak değerlendirmelerinin daha önce uzaktan eğitim tecrübelerinin olmamasiyla da ilgili olduğu da söylenebilir. Çünkü yapılan başlıca çalışmalar bilgisayar kullanma becerisi ve deneyimi, daha önce uzaktan eğitim uygulamalarından birine katılmış olmanın uzaktan eğitime yönelik tutumu olumlu yönde etkilediğini ortaya koymuştur (Bayburtlu, 2020; Brinkerhoff ve Koroghlanian, 2005; Chang ve Tung, 2008; Kışla, 2005).

Keyifli kategorisindeki metaforlar incelendiğinde öğreticilerin yabancılara uzaktan Türkçe öğretmeyi kolay, pratik, eğlenceli ve keyifli bulduğu fark edilmiştir. Bu sonuç, dijital çağda doğmuş olan 21. yüzyll bireylerinin günlük aktivitelerinden eğlenme şekillerine kadar çoğu şeyde teknolojiden faydalanarak yapmalarıyla ilgili olduğu söylenebilir (Bull ve Kajder, 2005; Davis, 2004; Foley, 2013; Hung, Hwang ve Huang, 2012; Yang ve Wu, 2012). Çünkü bu kategoride oluşturulan metaforların 1-3 yll çalışan 20-27 yaş arasında olan katılımcılar tarafından oluşturulduğu tespit edilmiştir. Emek kategorisine bakıldığında katılımcıların yabancılara uzaktan Türkçe öğretmeyi ön hazırlık gerektiren, zaman ayırmayı ve emek harcamayı gerektiren bir süreç olarak değerlendirdikleri fark edilmiştir. Elde edilen bu sonuç, teknolojiyi öğrenmenin zaman aldığı gerçeği ile örtüştüğü ancak öğrenmenin ve öğretmenin doğası gereği herhangi bir eğitimin de zaten zaman almasıyla ilgili olduğu söylenebilir (Lammers, 2012).

\section{Öneriler}

Weforum, güvenilir internet erişimi ve/veya teknolojisi olmayan bazı öğretmen/öğrencilerin dijital öğrenmeye katılmakta zorladıklarını; bu boşluk ülkeler arasında ve ülkeler içindeki dengesiz gelir dağılımdan kaynaklandığını dile getirmektedir (www.weforum.org). Bu araştırmaya katılanların 83 katılımcıdan 68’i ders verilen teknolojik aracı kişisel temin ettiği 74 kişi de interneti kişisel temin ettiği fark edilmiştir. Uzaktan eğitiminde yaşanan en büyük sorun olan alt yapı sorunun uzaktan Türkçe öğretiminde de yaşandığı fark edilmiştir. Uzaktan eğitim ile derslerin yürütüldüğü bir sistem de gerekli alt yapı yoksa derslerin yürütülemeyeceği göz önüne alınırsa önceliğin alt yapı sorununu çözmek olduğu söylenebilir.

Internet Society, covid-19 salgını nedeniyle 1 Nisan 2020 tarihi itibariyle 173 ülkede 1,5 milyar öğrencinin uzaktan eğitime geçiş yaptığını ifade etmiştir (internetsociety.org). Bununla birlikte salgının öğrenci, öğretmen ve velilerin dijital okuryazarlıklarını geliştirmeye yönelik acil bir ihtiyaç olduğunu dile getirmiştir. Dolayısıyla daha verimli ve güvenli bir uzaktan Türkçe öğretimi için yabancılara Türkçe öğretenlere ve öğrencilerine dijital okuryazarlık seminerleri verilebilir.

Uzaktan Türkçe öğretiminde Türkçe yazılımların ve içeriklerin yok denecek kadar az sayıda olmasından dolayı eş zamansız derslerin açık erişime sunulması, yabancılara Türkçe öğretimini içeren yazılımların geliştirilmesi, etkileşimli içerik paylaşım platformların kurulmasının bu alana hizmet edici bir rol üstleneceği düşünülmektedir.

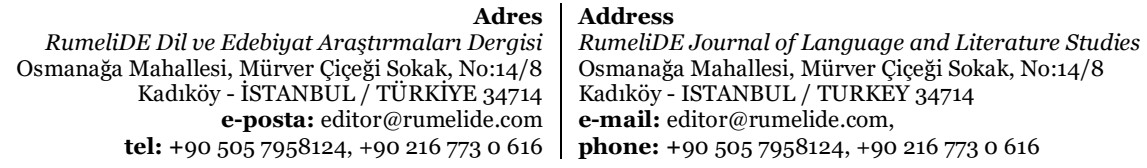




\section{Kaynakça}

Arslan, M.M. ve Bayrakcı, M. (2006). Metaforik düşünme ve öğrenme yaklaşımının eğitim-öğretim açısından incelenmesi. Milli Ĕ̆itim, 171, 100-108.

Aydın, C. H. (2011). Açı ve uzaktan öğrenme: öğrenci adaylarının bakış açısı. Ankara: Pegem Akademi.

Aykaç, N. ve Çelik, Ö. (2014), Öğretmenlerin ve öğretmen adaylarının eğitim programına ilişkin metaforik algılarının karşılaştırılması. Eğitim ve Bilim, 39(173), 328-34.

Bayburtlu,Y. S. (2020). Covid-19 Pandemi dönemi uzaktan eğitim sürecinde öğretmen görüşlerine göre Türkçe eğitimi. Turkish Studies, 15(4), 131-151.

Bozkurt, A. (2020). Koronavirüs (covid-19) pandemisi sirasinda ilköğretim öğrencilerinin uzaktan eğitime yönelik imge ve algilari: bir metafor analizi. Uşak Üniversitesi Eğitim Araştırmaları Dergisi, 6(2), 1- 23.

Brinkerhoff, J. ve Koroghlanian, C. M. (2005). Student computer skills and attitudes toward Internetdelivered instruction. Journal of Educational Computing Research, 32(1), 27-56.

Bull, G., ve Kajder, S. (2005). Digital storytelling in the language arts classroom. Learning \& Leading with Technology, 32(4), 46-49.

Chang, S.C. ve Tung, F.C. (2008). An empirical investigation of students' behavioural intentions to use the online learning course websites. British Journal of Educational Technology, 39(1),71-83.

Çallı, İ., İşman, A., ve Torkul, O. (2001) Sakarya üniversitesi’nde açık ve uzaktan öğrenmenin dünü, bugünü ve geleceği. 1.Uluslararası Eğitim Teknolojileri Sempozyumu ve Fuarı. Sakarya: Sakarya Üniversitesi.

Davis, A. (2004) Co-authoring identity: digital storytelling in an urban middle school. THEN: Technology, Humanities, Education and Narrative, 1, 1-12.

Demircan, Ö. (2002). Yabancl-dil öğretim yöntemleri. İstanbul: Der.

Durak, G., Çankaya S. ve İzmirli, S. (2020). Covid-19 pandemi döneminde Türkiye'deki üniversitelerin uzaktan eğitim sistemlerinin incelenmesi. Necatibey Eğitim Fakültesi Elektronik Fen ve Matematik Ĕ̆itimi Dergisi (EFMED), 14(1), 787-809.

Foley, M.L. (2013). Digital storytelling in primary-grade classrooms (Ph.D. thesis). Arizona State University, Pheonix.

Güngör, H., Çangal, Ö. ve Demir, T. (2020). Türkçenin yabancı dil olarak uzaktan öğretimine ilişkin öğrenici ve öğretici görüssleri. Gazi Üniversitesi Gazi Ĕ̆itim Fakültesi Dergisi, 4O(3), 1163-1191.

Horzum, M. B., Özkaya, M., Demirci, M. ve Alpaslan M. (2013). Türkçe uzaktan eğitim araştırmalarının incelenmesi. İnönü Üniversitesi Ĕ̆itim Fakültesi Dergisi, 14(2), 79-100.

Hung, C. M., Hwang, G. J., ve Huang, I. (2012). A project-based digital storytelling approach for improving students' learning motivation, problem-solving competence and learning achievement. Educational Technology \& Society, 15(4), 368-379.

InternetSociety. Erişim adresi: https://www.internetsociety.org

Kaplan, K. ve Gülden, B. (2021). Öğretmen görüşlerine göre salgın (COVID-19) dönemi uzaktan eğitim ortamında Türkçe eğitimi. RumeliDE Dil ve Edebiyat Araştırmaları Dergisi, (24), 233-258.

Karakuş, N., Ucuzsatar, N., Karacaoğlu, M. Ö., Esendemir, N. ve Bayraktar, D. (2020). Türkçe öğretmeni adaylarının uzaktan eğitime yönelik görüşleri. RumeliDE Dil ve Edebiyat Araştırmaları Dergisi, (19), 220-241.

Karatay, H., Kaya, S. ve Başer, D. (2021). Türkçenin yabancı dil olarak öğretiminde uzaktan eğitime yönelik öğrenci görüşleri. RumeliDE Dil ve Edebiyat Araştırmaları Dergisi, (24), 223-232.

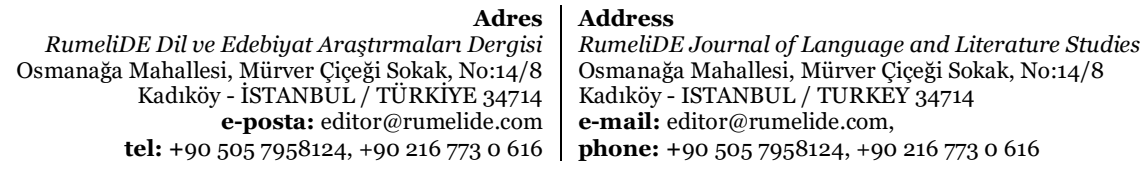


Karatepe, F., Küçükgençay, N. ve Peker, B. (2020). Öğretmen adayları senkron uzaktan eğitime nasıl bakıyor? Bir anket çalışması. Journal of Social and Humanities Sciences Research, 7(53), 12621274.

Kışla, T. (2005). Üniversite öğrencilerinin uzaktan eğitime yönelik tutumları. Yayımlanmamış yüksek lisans tezi, İzmir: Ege Üniversitesi.

Lammers, W. P. (2012). Digital storytelling : building 21st century literacy skills in the secondary classroom (Master thesis). University of Northern Iowa.

Melanlığlu, D. (2003). Yabancılara Türkçe öğretimi el kitabı (Ed. M. Durmuş ve A. Okur). Ankara: Grafiker.

Mutlu, H. H. (2020). Yabancı dil olarak Türkçe öğretiminde kullanılan c1 seviye ders kitaplarındaki kültür unsurlarının incelenmesi (Gazi yabancllar için Türkçe - İstanbul yabancılar için Türkçe). Dil Dergisi, 171(1), 91-108.

Okur, A. (2013). Millî kültür ve folklorun Türkçe ders kitapları aracıllğııla aktarımı. Adıyaman Üniversitesi Sosyal Bilimler Enstitüsü Dergisi Türkçenin Eğitimi Öğretimi Özel Sayısı, 11, 878904.

Okur, A. ve Keskin, F. (2013). Yabancılara Türkçe öğretiminde kültürel ögelerin aktarımı: İstanbul yabancllar için Türkçe öğretim seti örneği. The Journal of Academic Social Science Studies, 6(2), 1619-1640.

Özgül, E., Ceran, D. ve Yıldız, D. (2020). Uzaktan eğitimle yapilan Türkçe dersinin öğretmen görüşlerine göre değerlendirilmesi. Millî Eğitim, 49(Özel Sayı 1), 395-412.

Pilancı, H. (2018). Açlk ve uzaktan Türkçe öğrenenlerde etkileşim: eşzamansız iletişimde öğretim diyalogları. International Journal of Humanities and Education, 75-90.

Saban, A. (2008). İlköğretim I. kademe öğretmen ve öğrencilerinin bilgi kavramına ilişkin sahip oldukları zihinsel imgeler. İlköğretim Online, 7(2), 421-455.

Sarıtaş, E. ve Barutçu, S. (2020). Öğretimde dijital dönüsüm ve öğrencilerin çevrimiçi öğrenmeye hazır bulunuşluluğu: Pandemi döneminde Pamukkale Ửniversitesi öğrencileri üzerinde bir araştırma. IUYD, 11(1), 5-22.

Simonson, M., Smaldino, S., ve Zvacek, S. (2015). Teaching and learning at a distance: Foundations of distance education (6. Baskı). Information Age Publishing: USA.

Tapan, N. (1990). Yabancı dil olarak Almanca öğretiminde yeni bir yöneliş: kültürlerarsı-bildişim-odaklı yaklaşım. Alman Dili ve Edebiyatı Dergisi, IX, 149-167.

Tümen Akyıldız, S. (2020). Pandemi döneminde yapılan uzaktan eğitim çalışmalarıyla ilgili İngilizce öğretmenlerinin görüssleri (bir odak grup tartışması). RumeliDE Dil ve Edebiyat Araştırmaları Dergisi, (21), 679-696.

Weforum. Erişim adresi: https://www.weforum.org

Yang, Ya-T. C. ve Wu, Wan-C. I. (2012). Digital storytelling for enhancing student academic achievement, critical thinking, and learning motivation: a year-long experimental study. Computers \& Education, 59(2), 339-352.

Yıldırım, A. ve Şimşek H. (2013). Sosyal bilimlerde nitel araştırma yöntemleri (Genişletilmiş 9. Baskı). Ankara: Seçkin.

Yılmaz, G. K. ve Güven, B. (2015). Öğretmen adaylarının uzaktan eğitime yönelik algılarının metaforlar yoluyla belirlenmesi. Turkish Journal of Computer and Mathematics Education, 6(2), 299-322.

Yurdakul, Y. ve Duman, G. B. (2021). Uzaktan eğitimle Türkçenin yabancı dil olarak öğretimi sürecinde temel becerilerin gerçekleştirilebilme durumunun öğretici görüşleri üzerinden değerlendirilmesi. RumeliDE Dil ve Edebiyat Araştırmaları Dergisi, (23), 167-186.

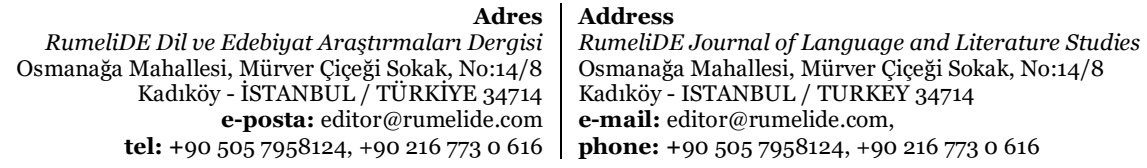

